\title{
PERBEDAAN NILAI KADAR AIR KAPASITAS LAPANG BERDASARKAN METODE ALHRICKS, DRAINASE BEBAS, DAN PRESSURE PLATE PADA BERBAGAI TEKSTUR TANAH DAN HUBUNGANNYA DENGAN PERTUMBUHAN BUNGA MATAHARI (Helianthus annuus L.)
}

\section{Different Levels of Field Capacity by Alhricks, Free Drainage, and Pressure Plate Methods at Different Soil Texture and Relation for Sunflower Growth (Helianthus annuus L.)}

\author{
Oteng Haridjaja1)*, Dwi Putro Tejo Baskoro1), dan Mahartika Setianingsih2) \\ 1) Departemen Ilmu Tanah dan Sumberdaya Lahan, Fakultas Pertanian IPB, Jl. Meranti Kampus IPB Darmaga \\ Bogor 16680 \\ 2) Alumni Program Studi Perencanaan dan Pengembangan Wilayah, Departemen Ilmu Tanah dan Sumberdaya \\ Lahan, Fakultas Pertanian IPB, Bogor 16680
}

\begin{abstract}
Soil water availability is one of the important factors influencing plant growth. Field capacity can be determined by different methods. The objective of this research was to compare among methods of field capacity measurement and to observe a response of sunflower growth. This research was initiated with field capacity measurement with methods, i.e. Alhricks, Free drainage, and Pressure Plate at different soil textures, i.e. clay, sandy clay loam, and sandy loam. Furthermore, sunflower planting with different watering treatment based on field capacity of each mentioned methods was carried out in greenhouse. The research was designed by completely randomized design factorial with three replications. The result showed that soil texture and field capacity method and interaction of both significantly affected a field capacity value. Field capacity on clay texture (62.18\%) was higher than sandy clay loam (20.42\%) and sandy loam (10.92\%). At determination of field capacity by Alhricks method, the best thickness of the quartz sand and soil are $6 \mathrm{~cm}$ and $3 \mathrm{~cm}$ because data obtained is more consistent and produce the highest $R^{2}$ value (0.967). In clay textured soil, watering treatment based on field capacity of each method did not significantly affect on plant height, number of leaves, stem diameter, and dry root biomass but significantly affected on wet root biomass, wet and dry canopy biomass, and root length. The result also showed that different texture will affect growth response of sunflower.
\end{abstract}

Keywords: Alhricks, field capacity, free drainage, pressure plate, sunflower

\begin{abstract}
ABSTRAK
Ketersediaan air dalam tanah merupakan salah satu faktor penting bagi pertumbuhan tanaman. Kadar air pada kapasitas lapang dapat ditetapkan dengan metode yang berbeda. Tujuan penelitian ini adalah untuk membandingkan berbagai metode pengukuran kadar air kapasitas lapang dan melihat responnya terhadap pertumbuhan bunga matahari. Penelitian ini diawali dengan penetapan kadar air kapasitas lapang (KAKL) dengan yaitu metode Alhricks, Drainase bebas, dan Pressure Plate terhadap tiga kelas tekstur tanah berbeda yaitu: liat, lempung liat berpasir, dan lempung berpasir. Selanjutnya di rumah kaca, dilakukan penanaman bunga matahari dengan perlakuan kombinasi perbedaan jenis tekstur dan pemberian air pada KAKL dari masing-masing metode. Rancangan percobaan yang digunakan adalah rancangan percobaan faktorial acak lengkap dengan 3 kali ulangan. Hasil penelitian menunjukkan bahwa tekstur dan metode penetapan serta interaksi keduanya berpengaruh nyata terhadap nilai KAKL. Kadar air kapasitas lapang (\% berat) pada tekstur liat (62.18\%) lebih besar dibandingkan tekstur lempung liat berpasir (20.42\%) dan lempung berpasir (10.92\%). Pada penetapan kadar air kapasitas lapang dengan metode Alhricks, ketebalan pasir kuarsa yang paling baik adalah $6 \mathrm{~cm}$ dan tanah $3 \mathrm{~cm}$, karena data kadar air yang diperoleh lebih konsisten serta menghasilkan nilai $\mathrm{R}^{2}$ yang paling tinggi (0.967). Pada tekstur liat perlakuan penyiraman yang didasarkan pada KAKL tidak berpengaruh nyata terhadap tinggi tanaman, jumlah daun, diameter batang, dan biomassa akar kering namun berpengaruh nyata terhadap biomassa akar basah, biomassa tajuk basah dan kering, serta panjang akar. Pada perlakuan tekstur, terlihat perbedaan respon pertumbuhan yang nyata antara tanaman bunga matahari yang ditanam pada tekstur liat, lempung liat berpasir, dan lempung berpasir.
\end{abstract}

Kata kunci: Alhricks, kadar air kapasitas lapang, drainase bebas, pressure plate, bunga matahari 


\section{PENDAHULUAN}

Air merupakan salah satu komponen penting bagi pertumbuhan dan perkembangan tanaman. Air yang diserap tanaman adalah air yang berada pada pori-pori tanah. Setiap jenis tanah memiliki distribusi dan ukuran pori yang berbeda-beda, yang akan mempengaruhi ketersediaan air di dalam tanah.

Tekstur tanah sangat mempengaruhi kemampuan tanah dalam memegang air. Tanah bertekstur liat memiliki kemampuan yang lebih besar dalam memegang air daripada tanah bertekstur pasir hal ini terkait dengan luas permukaan adsorptifnya. Semakin halus teksturnya akan semakin besar kapasitas menyimpan airnya.

Menurut Jury et al. (1991) dalam banyak kasus, kemampuan tanah menahan air dianggap setara dengan kadar air kapasitas lapang. Secara umum kadar air kapasitas lapang didefinisikan sebagai kadar air tanah di lapang pada saat air drainase sudah berhenti atau hampir berhenti mengalir karena adanya gaya grafitasi setelah sebelumnya tanah tersebut mengalami jenuh sempurna.

Kadar air kapasitas lapang dapat ditetapkan dengan tiga metode yang berbeda-beda, yaitu metode Alhricks, Drainase bebas, dan Pressure plate. Ketiga metode tersebut memiliki prinsip yang berbeda. Secara umum prinsip metode Alhricks dan Drainase bebas berdasarkan hilangnya air gravitasi, sedangkan metode Pressure plate berdasarkan tekanan setara pF 2.54 (1/3 atm). Menurut hasil penelitian Sulaeman (2011) terdapat perbedaan hasil yang nyata diantara metode Alhricks dan metode Pressure plate, yaitu kadar air yang dihasilkan oleh metode Pressure plate lebih kecil jika dibandingkan dengan metode Alhricks. Menurut Baskoro dan Tarigan (2007) perbedaaan nilai kadar air tersebut dapat disebabkan karena pemberian tekanan 1/3 atm pada penetapan dengan metode Pressure plate sebenarnya hanya merupakan pendekatan. Contoh tanah utuh yang digunakan dalam penetapan kadar air kapasitas lapang dengan metode Pressure plate hanya setebal $\pm 1 \mathrm{~cm}$. Air yang ada pada contoh tanah tersebut lebih mudah hilang dibandingkan dengan air dalam tanah dengan kolom yang tebal seperti pada metode Alhricks.

Penelitian ini bertujuan untuk membandingkan metode pengukuran kadar air pada kapasitas lapang dengan metode dan kelas tekstur yang berbeda, serta melihat responnya terhadap pertumbuhan tanaman bunga matahari.

\section{BAHAN DAN METODE}

Penelitian ini dilaksanakan di laboratorium Fisika dan Konservasi Tanah, Departemen Ilmu Tanah dan Sumberdaya Lahan untuk analisis bobot isi dan kadar air kapsitas lapang, sedangkan penanaman dilakukan di Rumah Kaca Kebun Percobaan Cikabayan University Farm IPB.

Bahan yang digunakan adalah contoh tanah Latosol dikering udarakan dan diayak dengan ayakan 2 mm (diambil di lokasi Cikabayan, Darmaga pada lapisan 0-20 cm), pasir kuarsa, pereaksi kimia $\left(\mathrm{H}_{2} \mathrm{SO}_{4}, \mathrm{HCl}\right.$, $\mathrm{K}_{2} \mathrm{Cr}_{2} \mathrm{O}_{7}, \mathrm{H}_{3} \mathrm{BO}_{4}, \mathrm{H}_{2} \mathrm{O}_{2}$, Na-Pirofosfat, indikator conway \& feroin), bibit bunga matahari varietas Velvet Queen, pupuk urea, SP-36, KCL, dan insektisida.
Peralatan yang digunakan adalah pressure plate apparatus, paralon, oven, timbangan, $\mathrm{pH}$ meter, spektrofotometer, flamefotometer, ayakan $2 \mathrm{~mm}$, pot, meteran, jangka sorong, peralatan gelas, dan peralatan lain yang diperlukan dalam penelitian.

\section{Pelaksanaan Penelitian}

Penelitian dilakukan dalam dua tahap percobaan yaitu:

(1) analisis awal tanah dan penetapan kadar air kapasitas lapang di laboratorium dengan 3 metode yang berbeda yaitu metode Alhricks, drainase bebas, dan pressure plate.

(2) percobaan pot yang dilakukan di rumah kaca dengan tanaman bunga matahari sebagai indikator. Bahan tanah yang digunakan merupakan hasil dari percampuran tanah Latosol dengan pasir kuarsa yang bersih (bebas liat dan debu), hal ini dimaksudkan untuk mendapatkan tekstur tanah yang berbeda. Rasio bahan tanah dan pasir yang digunakan adalah 1:0 atau merupakan asli tanah Latosol menghasilkan tekstur liat (T1), campuran 4:6 menghasilkan tekstur lempung liat berpasir (T2), dan 2:8 menghasilkan tekstur lempung berpasir (T3). Analisis tekstur tanah ditetapkan dengan metode pipet.

Analisis sifat-sifat tanah awal dilakukan terhadap setiap jenis tekstur tanah. Parameter yang dianalisis meliputi: P dan K tersedia (metode Bray 1), Nitrogen total (metode Kjeldahl), C-organik (metode Walkley\&Black), dan $\mathrm{pH}\left(\mathrm{H}_{2} \mathrm{O}\right.$ 1:1). Analisis sifat fisik tanah meliputi penetapan kadar air awal tanah $\left(\% \mathrm{KA}_{\text {awal }}\right)$ dengan metode gravimetri, dilakukan untuk mengetahui kadar air tanah awal sebelum adanya perlakuan, sehingga dapat ditetapkan jumlah air yang harus ditambahkan untuk mencapai kapasitas lapang tiap metode. Penetapan kadar air secara gravimetrik dilakukan dengan cara mengeringkan sekitar 10 gram sampel tanah dalam oven pada suhu $105^{\circ} \mathrm{C}$ selama 24 jam. Kadar air gravimetrik di hitung dengan rumus:

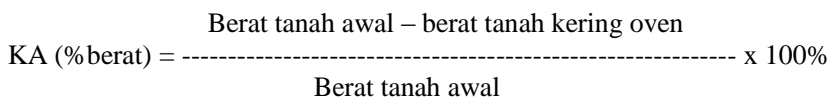

Bobot isi pada kondisi tanah dengan metode berat kering/volume, dan kadar air kapsitas lapang (KAKL) dengan tiga metode yaitu:

a. Alhricks

Tahapan pengerjaan sebagai berikut: gelas piala $500 \mathrm{ml}$ diisi dengan pasir kuarsa setinggi 1-2 cm, agar tanah tidak turun saat diketuk maka di atas pasir kuarsa diletakkan kain kasa. Pipa gelas diletakkan tegak lurus dengan permukaan pasir. Gelas piala diisi dengan contoh tanah kering udara sampai $3.5 \mathrm{~cm}$ dari tepi atas gelas. Gelas piala diketuk 50 kali ketukan. Lapisan tanah atas dibasahi dengan air dengan cara disemprot dengan sprayer namun air dikontrol agar tidak sampai membasahi pasir. Gelas piala ditutup dan disimpan selama 24 jam. Setelah 24 jam, diambil contoh tanah pada kedalaman kira-kira 2.5 cm dari permukaan dan ditetapkan kadar airnya berdasarkan bobot tanah kering oven $105^{\circ} \mathrm{C}$. Dilakukan pengukuran kadar air per interval waktu (setiap hari sampai kadar airnya relatif tetap), dan dibuat persamaan antar kadar air dan waktu. Pada metode ini dilakukan 3 
variasi ketebalan pasir kuarsa dan tanah, yaitu: variasi 1 (pasir kuarsa setebal $2 \mathrm{~cm}$ dan tanah setebal $6 \mathrm{~cm}$ ), variasi 2 (pasir kuarsa setebal $6 \mathrm{~cm}$ dan tanah setebal $3 \mathrm{~cm}$ ), variasi 3 (pasir kuarsa setebal $10 \mathrm{~cm}$ dan tanah setebal 10 $\mathrm{cm})$.

b. Drainase bebas

Tahapan pengerjaan sebagai berikut: masingmasing tekstur tanah dimasukkan ke dalam masing-masing paralon yang bagian bawahnya sudah ditutup dengan kasa strimin dan diletakkan di atas tatakan. Contoh tanah diberi air hingga jenuh atau sampai ada air yang terdrainase melalui celah kasa strimin. Paralon ditutup dengan plastik wrap dan didiamkan selama 24 jam. Contoh tanah diambil dan ditetapkan kadar airnya seperti metode Alhricks.

c. Pressure plate ( $\mathrm{pF} 2.54)$

Tahapan pengerjaan sebagai berikut: contoh tanah kering udara ditimbang dan dimasukkan ke dalam ring sample sesuai dengan bobot isi yang telah didapatkan. Ring sample tersebut disusun pada pressure plate apparatus kemudian dijenuhkan selama \pm 24 jam. Kemudian dimasukkan ke dalam panci atau alat $\mathrm{pF}$ dan diberikan tekanan $1 / 3$ atm atau $\mathrm{pF} 2.54$. Ditunggu sampai tetesan air berhenti (48 jam) kemudian tanah diangkat dan ditetapkan kadar airnya. Penetapan kadar air dilakukan secara gravimetri.

Nilai kadar air kapasitas lapang yang dihasilkan dari percobaan di laboratorium (\% KAKL) digunakan sebagai dasar pemberian air pada percobaan pot di rumah kaca.

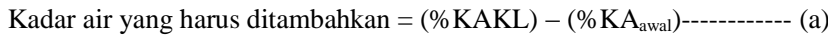

Tahap selanjutnya adalah percobaan pot di rumah kaca dengan tanaman bunga matahari. Biji bunga matahari disemai dalam media yang berisi campuran tanah dan kompos (1:1). Setelah tinggi bibit sekitar $15-20 \mathrm{~cm}$, dipindahkan ke pot percobaan. Tiap pot berisi $7.5 \mathrm{~kg}$ tanah (BKU). Diberikan kompos dan pupuk dasar sesuai dengan dosis berdasarkan hasil analisis awal tanah. Bobot isi media tanam dalam pot disesuaikan dengan hasil analisis di laboratorium yaitu $0.86 \mathrm{~g} \mathrm{~cm}^{-3}$ untuk tekstur liat, $1.23 \mathrm{~g}$ $\mathrm{cm}^{-3}$ untuk tekstur lempung liat berpasir, dan $1.36 \mathrm{~g} \mathrm{~cm}^{-3}$ untuk tekstur lempung berpasir. Pengaturan air dilakukan sesuai dengan masing-masing perlakuan.

Rancangan percobaan yang digunakan adalah Rancangan Faktorial Acak Lengkap (RAL). Faktor pertama adalah tekstur tanah yang terdiri dari 3 taraf yaitu liat, lempung liat berpasir, dan lempung berpasir. Faktor kedua adalah penyiraman yang terdiri dari 3 taraf yaitu didasarkan pada nilai KAKL yang diukur dengan metode Alhricks, Drainase bebas, dan Pressure plate. Kadar air di dalam pot dipertahankan pada kondisi kapasitas lapang dengan perhitungan seperti pada rumus (a). Pengecekan dilakukan 2 kali sehari (pagi dan sore). Dasar penyiraman berbasis bobot kering udara (BKU) yang tetap. Total perlakuan adalah 9 perlakuan dan masing-masing perlakuan diulang sebanyak 3 kali, berdasarkan kombinasi tersebut, sehingga terdapat 27 satuan percobaan. Adapun jenis perlakuan tersebut adalah sebagai berikut:

tanah bertekstur liat dengan KAKL

$1 \mathrm{M} 1$ metode Alhricks tanah bertekstur liat dengan KAKL tanah bertekstur liat dengan KAKL metode Pressure plate tanah bertekstur lempung liat berpasir dengan KAKL metode Alhricks tanah bertekstur lempung liat berpasir dengan KAKL metode Drainase bebas tanah bertekstur lempung liat berpasir dengan KAKL metode Pressure plate tanah bertekstur lempung berpasir dengan KAKL metode Alhricks tanah berteksturlempung berpasir dengan KAKL metode Drainase bebas tanah bertekstur lempung berpasir dengan KAKL metode Pressure plate

Pengukuran parameter pertumbuhan meliputi tinggi tanaman, jumlah daun, dan diameter batang, diamati setiap minggu mulai 0 MST (Minggu Setelah Transplanting), kecuali diameter batang pada 2 MST. Setelah tanaman panen yaitu pada 10 MST dilakukan pengukuran panjang akar, bobot basah dan kering akar dan tajuk tanaman.

\section{HASIL DAN PEMBAHASAN}

\section{Analisis Tanah Awal}

Hasil analisis sifat fisik tanah awal menunjukkan bahwa tanah latosol (T1) memiliki tekstur liat dengan kandungan pasir, debu, dan liat masing-masing sebesar $5 \%$, $19 \%$, dan $76 \%$ sedangkan bobot isi sebesar 0.86 $\mathrm{g} / \mathrm{cm}^{3}$. Contoh tanah simulasi yaitu T2 dan T3 masingmasing memiliki tekstur lempung liat berpasir dan lempung berpasir dengan bobot isi masing-masing sebesar $1.23 \mathrm{~g} \mathrm{~cm}^{-3}$ dan $1.36 \mathrm{~g} \mathrm{~cm}^{-3}$.

Tabel 1. Hasil analisis sifat fisik berbagai tekstur tanah

\begin{tabular}{|c|c|c|c|c|c|}
\hline $\begin{array}{l}\text { Perlakua } \\
\mathrm{n}\end{array}$ & $\begin{array}{c}\text { Pasir } \\
(\%)\end{array}$ & $\begin{array}{c}\text { Debu } \\
(\%)\end{array}$ & $\begin{array}{l}\text { Liat } \\
(\%)\end{array}$ & Tekstur & $\begin{array}{l}\text { Bobot isi } \\
\left(\mathrm{g} \mathrm{cm}^{-3}\right)\end{array}$ \\
\hline $\mathrm{T} 1$ & 5 & 19 & 76 & Liat & 0.86 \\
\hline $\mathrm{T} 2$ & 62 & 8 & 30 & $\begin{array}{l}\text { Lempung liat } \\
\text { berpasir }\end{array}$ & 1.23 \\
\hline $\mathrm{T} 3$ & 81 & 4 & 15 & $\begin{array}{l}\text { Lempung } \\
\text { berpasir }\end{array}$ & 1.36 \\
\hline
\end{tabular}

Berdasarkan Tabel 1 terlihat bahwa bobot isi tertinggi adalah tanah dengan tekstur lempung berpasir sedangkan terendah adalah tekstur liat. Tanah dengan ruang pori total tinggi, cenderung mempunyai bobot isi yang lebih rendah. Tanah bertekstur liat memiliki ruang pori total yang tinggi sehingga memiliki bobot isi yang lebih rendah. Sebaliknya tanah berpasir total ruang porinya lebih kecil sehingga bobot isinya menjadi lebih besar (Kurnia et al., 2006). Pada tanah berpasir, walaupun ruang pori sedikit, gerakan udara, dan air sangat cepat karena adanya dominasi pori makro.

Menurut Rusdi (2003) tinggi rendahnya bobot isi juga dipengaruhi oleh bahan organik yang dikandung. Pada Tabel 2 menunjukkan bahwa tanah dengan tekstur lempung berpasir memiliki kadar C-organik yang paling rendah jika dibandingkan dengan tanah bertekstur liat dan lempung liat berpasir. 
Tabel 2. Hasil analisis sifat kimia berbagai tekstur tanah

\begin{tabular}{lccc}
\hline Parameter & Satuan & Nilai & Kategori \\
\hline Tekstur liat & & & \\
P tersedia & ppm & 3.34 & Sangat rendah \\
K & me $100 \mathrm{~g}^{-1}$ & 0.31 & Rendah \\
N total & $\%$ & 0.17 & Rendah \\
C-organik & $\%$ & 2.68 & Sedang \\
pH & - & 4.3 & Masam \\
Tekstur lempung liat berpasir & & \\
P tersedia & ppm & 5.51 & Rendah \\
K tersedia & me 100 g & 0.06 & Sangat rendah \\
N total & $\%$ & 0.06 & Sangat rendah \\
C-organik & $\%$ & 0.86 & Sangat rendah \\
pH & - & 6.2 & Agak masam \\
Tekstur lempung berpasir & & & \\
P tersedia & ppm & 5.02 & Rendah \\
K tersedia & me 100 g & 0.04 & Sangat rendah \\
N total & $\%$ & 0.03 & Sangat rendah \\
C-organik & $\%$ & 0.46 & Sangat rendah \\
pH & - & 6.5 & Agak masam \\
\hline Keterangan: & Pengkelasan & berdasarkan kriteria Balai & Penelitian Tanah \\
\multicolumn{2}{c}{ (2005) } & \multicolumn{3}{c}{}
\end{tabular}

Pada bahan tanah bertekstur liat pada umumnya memiliki kandungan $\mathrm{N}$ total, $\mathrm{K}$ tersedia, C-organik yang lebih tinggi jika dibandingkan dengan tanah bertekstur lempung liat berpasir dan lempung berpasir, namun kandungan $\mathrm{P}$ tersedia pada tanah bertekstur liat lebih rendah daripada kedua tekstur lainnya. Hal ini disebabkan karena pada tanah bertekstur liat memiliki pH yang lebih rendah. Ketersediaan $\mathrm{P}$ tertinggi terjadi pada selang $\mathrm{pH}$ 6.0-6.5. Pada $\mathrm{pH}$ yang lebih rendah dari nilai ini, aktivitas $\mathrm{P}$ berkurang karena retensi $\mathrm{R}_{2} \mathrm{O}_{3}$ dan di atas $\mathrm{pH}$ ini diretensi oleh ion-ion $\mathrm{Ca}$ dan $\mathrm{Mg}$ ataupun $\mathrm{CaCO}_{3}$ Leiwakabessy (2003).

\section{Pengaruh Ketebalan Pasir dan Tanah terhadap KAKL Metode Alhricks}

Pada penetapan KAKL dengan metode Alhricks digunakan pasir kuarsa dan tanah dengan ketebalan yang berbeda. Hasil analisis KAKL pada variasi 1 menghasilkan data kadar air yang justru mengalami peningkatan dari hari ke hari. Pada variasi ini, kadar air pada tekstur liat mengalami penurunan dari hari pertama ke hari ke-2, yaitu dari $51.77 \%$ menjadi $51.28 \%$, namun kadar airnya naik pada hari ke-3, yaitu sebesar 53.11\%. Pada hari ke-4 kadar airnya turun menjadi $51.45 \%$ namun pada hari ke-5 naik lagi menjadi $53.61 \%$. Begitu pula yang terjadi pada tanah bertekstur lempung liat berpasir dan lempung berpasir. Pada tanah bertekstur lempung liat berpasir terjadi penurunan kadar air dari hari pertama sampai hari ke-3 yaitu dari $24.8 \%$ menjadi $23.06 \%$, dan turun lagi menjadi $22.97 \%$, namun mengalami kenaikan pada hari ke-4 dan ke-5 yaitu menjadi $23.37 \%$, naik lagi menjadi $24.16 \%$. Pada tekstur lom berpasir justru terjadi kenaikan kadar air dari hari pertama ke hari ke-2 yaitu $15.12 \%$ menjadi $16.87 \%$, namun mengalami penurunan pada hari ke-3 sampai ke-4 yaitu $5.33 \%$ menjadi $13.75 \%$ dan naik lagi pada hari ke-5 menjadi $15.18 \%$. Peningkatan kadar air ini terjadi diduga adanya gejala kapilaritas karena tebal pasir kuarsa yang terlalu tipis. Karena ketidak konsistenan data sehingga digunakan variasi yang lain. Pada variasi 2, hasil yang diperoleh cukup baik karena dari hari ke hari nilai kadar air mengalami penurunan. Hasil kadar air dengan variasi 3 tidak sebaik pada varias 2 karena terdapat penyimpangan seperti yang dialami pada variasi 1 . Pada variasi 3 diduga masih terdapat gejala kapilaritas.

Penetapan KAKL metode Alhricks dengan variasi 2 lebih baik daripada variasi-variasi lainnya karena menghasilkan persamaan yang memiliki nilai $\mathrm{R}^{2}$ lebih dari 0.9 (tersaji pada Tabel 3) atau paling tinggi, selain itu nilai KAKL pada variasi 2 menghasilkan data yang lebih konsisten yaitu tidak terjadi kenaikan kadar air pada hari selanjutnya. Pada ketebalan pasir yang lebih besar, air akan terdrainase bebas ke lapisan pasir karena pengaruh gaya gravitasi dan kemungkinan terjadinya kapilaritas lebih kecil karena jarak tempuh air gravitasi semakin jauh. Jika ketebalan pasir rendah maka air akan lebih cepat mengisi pori makro sehingga pasir menjadi jenuh.

Penurunan kadar air pada penetapan KAKL dengan metode Alhricks pada berbagai variasi ketebalan pasir dan tanah dapat dilihat pada Gambar 1.

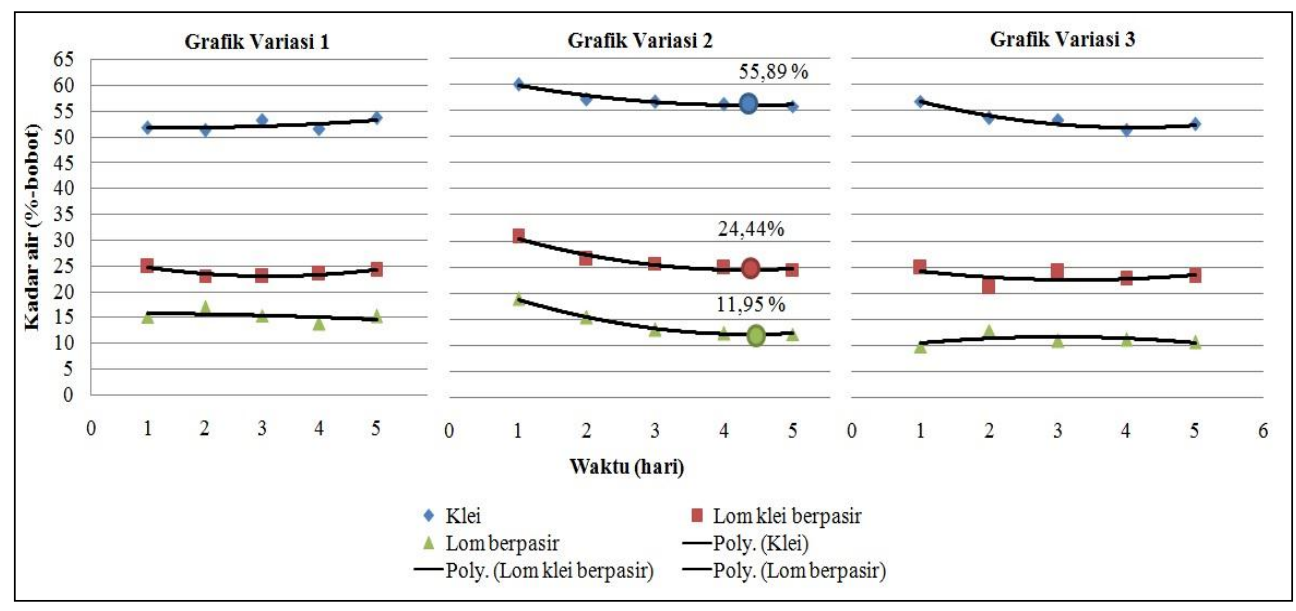

Gambar 1. Kadar air kapasitas lapang metode Alhricks pada berbagai ketebalan pasir kuarsa dan tanah 
Tabel 3. Persamaan polynomial (hubungan antara hari dan kadar air), koefisien determinasi $\left(\mathrm{R}^{2}\right)$, dan nilai kadar air kapasitas lapang pada tiap variasi dan tekstur tanah

\begin{tabular}{lcccc}
\hline Jenis tekstur tanah & Variasi & Persamaan polinomial & $\begin{array}{c}\text { Koefisien } \\
\text { determinasi } \\
\left(\mathrm{R}^{2}\right)\end{array}$ & $\begin{array}{c}\text { Kadar air } \\
\text { kapasitas lapang } \\
(\% \text {-bobot })\end{array}$ \\
\hline \multirow{2}{*}{ Liat } & 1 & $\mathrm{y}=0.129 \mathrm{x}^{2}-0.390 \mathrm{x}+51.99$ & 0.390 & 51.70 \\
& 2 & $\mathrm{y}=0.344 \mathrm{x}^{2}-2.981 \mathrm{x}+62.35$ & 0.948 & 55.89 \\
& 3 & $\mathrm{y}=0.521 \mathrm{x}^{2}-4.260 \mathrm{x}+60.47$ & 0.941 & 51.76 \\
\hline \multirow{2}{*}{$\begin{array}{l}\text { Lempung } \\
\text { liat berpasir }\end{array}$} & 1 & $\mathrm{y}=0.407 \mathrm{x}^{2}-2.560+26.88$ & 0.925 & 22.85 \\
& 2 & $\mathrm{y}=0.544 \mathrm{x}^{2}-4.691 \mathrm{x}+34.55$ & 0.956 & 24.44 \\
Lempung & 3 & $\mathrm{y}=0.290 \mathrm{x}^{2}-1.901 \mathrm{x}+25.68$ & 0.178 & 22.56 \\
berpasir & 1 & $\mathrm{y}=-0.048 \mathrm{x}^{2}-0.008 \mathrm{x}+15.81$ & 0.190 & 15.81 \\
& 2 & $\mathrm{y}=0.597 \mathrm{x}^{2}-5.238 \mathrm{x}+23.44$ & 0.997 & 11.95 \\
\hline
\end{tabular}

\section{Pengaruh Tekstur dan Metode Pengukuran terhadap Nilai Kadar Air Kapasitas Lapang}

Berdasarkan analisis ragam menunjukkan bahwa faktor tekstur tanah, metode pengukuran kadar air kapasitas lapang serta interaksi keduanya berpengaruh sangat nyata terhadap nilai kadar air kapasitas lapang. Hasil analisis kadar air kapasitas lapang berdasarkan uji lanjut Duncan tersaji pada Tabel 4.

Berdasarkan Tabel 4 dapat dilihat nilai kadar air kapasitas lapang antara ketiga tekstur berbeda nyata. Kadar air kapasitas lapang pada tekstur liat (T1) lebih besar daripada tekstur lempung liat berpasir (T2) dan lempung berpasir (T3). Kadar air kapasitas lapang pada T1, T2, dan T3 masing-masing sebesar $62.18 \%, 20.42 \%$, dan $10.92 \%$ secara berurutan. Hal ini disebabkan karena kapasitas menahan air (water holding capacity) tanah bertekstur liat lebih besar daripada tanah bertekstur lempung liat berpasir dan lempung berpasir. Nilai kadar air kapasitas lapang pada ketiga metode terlihat berbeda nyata. Kadar air kapasitas lapang pada M3 nilainya paling besar yaitu $34.81 \%$, sedangkan kadar air kapasitas lapang pada M1 dan M2 nilainya berturut-turut sebesar $30.76 \%$ dan 27.94\%. Menurut Sulaeman (2011) hal ini diduga karena terjadi penyumbatan pori kapiler pada pengukuran kadar air dengan menggunakan metode Pressure plate, akibatnya saat contoh tanah ditekan dengan tekanan 1/3 atm di dalam pressure plate apparatus air tidak sepenuhnya bergerak ke bawah. Hal ini menyebabkan kandungan air yang terukur lebih besar.

Tabel 4. Nilai kadar air kapasitas lapang (\%-bobot) pada berbagai tekstur tanah yang diukur dengan metode berbeda yaitu Alhricks, drainase bebas, dan Pressure Plate

\begin{tabular}{|c|c|c|c|c|}
\hline \multirow{2}{*}{$\begin{array}{l}\text { Metode pengukuran } \\
\text { KAKL }\end{array}$} & \multicolumn{3}{|c|}{ Tekstur } & \multirow{2}{*}{$\begin{array}{l}\text { Rata-Rata } \\
\text { (metode) }\end{array}$} \\
\hline & Liat (T1) & $\begin{array}{l}\text { Lempung liat } \\
\text { berpasir (T2) }\end{array}$ & $\begin{array}{c}\text { Lempung berpasir } \\
\text { (T3) }\end{array}$ & \\
\hline Alhricks (M1) & $55.89 \mathrm{~b}$ & $24.44 \mathrm{c}$ & $11.95 \mathrm{e}$ & $30.76 \mathrm{~b}$ \\
\hline Drainase bebas (M2) & $54.13 \mathrm{~b}$ & $17.97 \mathrm{~d}$ & $11.72 \mathrm{e}$ & $27.94 \mathrm{c}$ \\
\hline Pressure plate (M3) & $76.53 \mathrm{a}$ & $18.81 \mathrm{~d}$ & 9.09 ef & $34.81 \mathrm{a}$ \\
\hline Rata-Rata (tekstur) & $62.18 \mathrm{a}$ & $20.42 b$ & $10.92 \mathrm{c}$ & \\
\hline
\end{tabular}

Keterangan: Angka yang diikuti oleh huruf yang berbeda pada kolom dan baris yang diarsis menunjukkan berbeda nyata menurut uji $D u n c a n$ pada taraf 5\%. Angka yang diikuti huruf yang berbeda pada kolom rata-rata (metode) menunjukkan berbeda nyata menurut uji Duncan pada taraf 5\%, angka yang diikuti huruf yang berbeda pada baris rata-rata (tekstur) menunjukkan berbeda nyata menurut uji Duncan pada taraf $5 \%$.

Berdasarkan data yang diperoleh dari hasil pengukuran, kadar air kapasitas lapang pada tekstur liat yang diukur dengan metode Pressure plate menghasilkan nilai yang paling tinggi yaitu sebesar $76.53 \%$. Hal ini terjadi karena contoh tanah yang digunakan pada pengukuran KAKL dengan metode Pressure plate merupakan tanah terganggu yang memiliki partikel sangat lepas (tidak memiliki struktur) dan tidak teragregasi dengan baik walaupun sudah dilakukan inkubasi. Pada saat proses penjenuhan terjadi perpecahan agregat tanah menjadi butir-butir tanah yang berukuran lebih kecil (slaking). Slaking ini dapat terjadi akibat agregat tidak cukup kuat bertahan terhadap tekanan yang dihasilkan oleh swelling (pembengkan), udara terjerap, pelapasan panas secara cepat selama pembasahan, dan tindakan mekanik pergerakan air (Lado et al., 2004). Akibatnya pada saat contoh tanah dijenuhkan menjadi over jenuh kemudian saat ditekan dengan tekanan 1/3 atmosfir air menjadi terjebak karena inkontinuitas pori, sehingga kadar air yang terukur menjadi lebih besar. Menurut hasil penelitian Hasugian (1994) bahwa tanah dengan tekstur liat mencapai kapasitas lapang pada $\mathrm{pF} 3.50$ sedangkan tanah dengan tekstur lempung liat berpasir mencapai kapasitas lapang pada pF 2.50. Menurut Supriyanto (1996) tanah bertekstur lempung dan pasir nilai kapasitas lapang mendekati tegangan air pada $\mathrm{pF} 2$. 
Pada tanah bertekstur kasar, KAKL yang diukur dengan metode Pressure plate nilainya relatif kecil, yaitu $18.81 \%$ pada tekstur lempung liat berpasir dan $9.09 \%$ pada tekstur lempung berpasir, hal ini disebabkan karena bahan tanah yang digunakan merupakan tanah terganggu hasil percampuran antara tanah dan pasir kuarsa. Bahan tanah tersebut memiliki partikel yang masih sangat lepas, tidak memiliki struktur dan tidak teragregasi. Cara pengukuran KAKL dengan metode Pressure plate yang seharusnya menggunakan contoh tanah utuh (tidak terganggu) juga dapat mempengaruhi nilai KAKL yang dihasilkan.

Pengukuran dengan metode Alhricks dijadikan standar karena metode pengerjaannya sesuai dengan definisi kapasitas lapang yang menganggap terjadinya pengisian pori-pori kapiler oleh air yang bergerak secara gravitasi. Metode ini juga mewakili keadaan tanah yang sebenarnya di lapang karena pada lapisan bawah terdapat pasir kuarsa, berbeda halnya dengan metode Drainase bebas yang mana di tanah tersebut tidak terdapat lapisan penahan sehingga air dengan bebas terdrainase.

\section{Pengaruh Pemberian Air Berdasarkan KAKL yang Diukur dengan Metode Berbeda terhadap Pertumbuhan Tanaman Bunga Matahari pada Tekstur Liat}

Tanaman bunga matahari yang ditanam pada media tanah bertekstur liat, seluruhnya dapat hidup normal sampai panen (10 MST) sedangkan tanaman yang ditanam pada media tanah bertekstur lempung liat berpasir dan lempung berpasir hanya dapat bertahan hidup sampai umur 1-2 MST, oleh karena itu untuk melihat pengaruh pemberian air berdasarkan KAKL yang diukur dengan metode berbeda hanya dapat dilihat berdasarkan pertumbuhan tanaman pada tekstur liat. Hal ini disebabkan karena kadar air pada tekstur lempung liat berpasir dan lempung berpasir terlalu rendah (9.09\% sampai $24.44 \%)$ sehingga tidak mencukupi kebutuhan tanaman untuk masa pertumbuhannya. Faktor penyebab lain adalah diduga karena pemupukan urea yang berlebihan pada konsentrasi kadar air yang rendah, hal ini mengakibatkan konsentrasi $\mathrm{N}$ menjadi lebih pekat, sehingga tanaman mati karena keracunan $\mathrm{N}$.

Tabel 5. Pengaruh penyiraman berdasarkan KAKL yang diukur dengan metode yang berbeda terhadap tinggi tanaman $(\mathrm{cm})$

\begin{tabular}{|c|c|c|c|}
\hline \multirow{2}{*}{$\begin{array}{c}\text { Umur } \\
\text { Tanaman } \\
\text { (MST) }\end{array}$} & \multicolumn{3}{|c|}{ Metode Penetapan Kadar Air Kapasitas Lapang } \\
\hline & $\begin{array}{c}\text { Metode Alhricks (KAKL } \\
55.89 \%-B)\end{array}$ & $\begin{array}{c}\text { Metode Drainase Bebas } \\
\text { (KAKL 54.13\%-B) }\end{array}$ & $\begin{array}{l}\text { Metode Pressure Plate } \\
\text { (KAKL 76.53-B) }\end{array}$ \\
\hline 0 & $15.23 \mathrm{a}$ & $12.50 \mathrm{a}$ & $17.20 \mathrm{a}$ \\
\hline 1 & $27.17 \mathrm{a}$ & $27.43 \mathrm{a}$ & $28.27 \mathrm{a}$ \\
\hline 2 & $48.00 \mathrm{a}$ & $47.17 \mathrm{a}$ & $48.90 \mathrm{a}$ \\
\hline 3 & $65.93 \mathrm{a}$ & $69.83 \mathrm{a}$ & $75.33 \mathrm{a}$ \\
\hline 4 & $86.17 \mathrm{a}$ & $90.90 \mathrm{a}$ & $103.73 \mathrm{a}$ \\
\hline 5 & $99.83 \mathrm{a}$ & $106.33 \mathrm{a}$ & $127.17 \mathrm{a}$ \\
\hline 6 & $102.17 \mathrm{a}$ & $113.10 \mathrm{a}$ & $135.33 \mathrm{a}$ \\
\hline 7 & $102.03 \mathrm{a}$ & $113.60 \mathrm{a}$ & $135.50 \mathrm{a}$ \\
\hline 8 & $101.83 \mathrm{a}$ & $113.57 \mathrm{a}$ & $133.00 \mathrm{a}$ \\
\hline 9 & $101.10 \mathrm{a}$ & $114.20 \mathrm{a}$ & $132.67 \mathrm{a}$ \\
\hline 10 & $101.10 \mathrm{a}$ & $114.20 \mathrm{a}$ & $133.00 \mathrm{a}$ \\
\hline
\end{tabular}

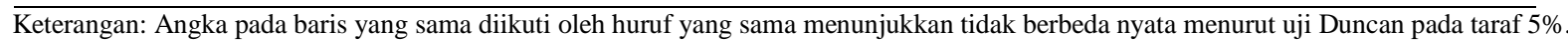

Tabel 6. Pengaruh penyiraman berdasarkan KAKL yang diukur dengan metode yang berbeda terhadap jumlah daun tanaman

\begin{tabular}{|c|c|c|c|}
\hline \multirow{2}{*}{$\begin{array}{l}\text { Umur } \\
\text { Tanaman } \\
\text { (MST) }\end{array}$} & \multicolumn{3}{|c|}{ Metode Penetapan Kadar Air Kapasitas Lapang } \\
\hline & $\begin{array}{c}\text { Metode Alhricks (KAKL } \\
55.89 \%-\mathrm{B})\end{array}$ & $\begin{array}{l}\text { Metode Drainase Bebas } \\
\text { (KAKL 54.13\%-B) }\end{array}$ & $\begin{array}{l}\text { Metode Pressure Plate } \\
\text { (KAKL 76.53-B) }\end{array}$ \\
\hline 0 & $9 \mathrm{a}$ & $7 \mathrm{a}$ & $7 \mathrm{a}$ \\
\hline 1 & $14 \mathrm{a}$ & $13 \mathrm{a}$ & $11 \mathrm{a}$ \\
\hline 2 & $17 \mathrm{a}$ & $17 \mathrm{a}$ & $17 \mathrm{a}$ \\
\hline 3 & $26 \mathrm{a}$ & $19 \mathrm{a}$ & $20 \mathrm{a}$ \\
\hline 4 & $56 \mathrm{a}$ & $31 \mathrm{a}$ & $55 \mathrm{a}$ \\
\hline 5 & $64 \mathrm{a}$ & $38 \mathrm{a}$ & $71 \mathrm{a}$ \\
\hline 6 & $72 \mathrm{a}$ & $39 \mathrm{a}$ & $74 \mathrm{a}$ \\
\hline 7 & $71 \mathrm{a}$ & $45 \mathrm{a}$ & $76 \mathrm{a}$ \\
\hline 8 & $66 \mathrm{a}$ & $47 \mathrm{a}$ & $80 \mathrm{a}$ \\
\hline 9 & $64 \mathrm{a}$ & $41 \mathrm{a}$ & $63 \mathrm{a}$ \\
\hline 10 & $64 \mathrm{a}$ & $41 \mathrm{a}$ & $63 \mathrm{a}$ \\
\hline
\end{tabular}

Keterangan: Angka pada baris yang sama diikuti oleh huruf yang sama menunjukkan tidak berbeda nyata menurut uji Duncan pada taraf $5 \%$.

Tinggi Tanaman. Pada tanah bertekstur liat, pengaruh penyiraman berdasarkan KAKL yang diukur dengan metode berbeda, tidak berpengaruh nyata terhadap tinggi tanaman pada umur 0-10 minggu setelah tanam (MST). Tabel 5 memperlihatkan adanya peningkatan tinggi tanaman yang terlihat jelas pada minggu ke-1 sampai ke-5. Pada umur 0-4 MST tanaman berada pada fase vegetatif sedangkan mulai 5 MST memasuki fase generatif ditandai dengan munculnya bunga.

Jumlah Daun. Berdasarkan hasil sidik ragam pengaruh penyiraman berdasarkan KAKL yang diukur dengan metode berbeda tidak berpengaruh nyata terhadap jumlah daun pada umur 0-10 MST. 
Meskipun demikian dapat dilihat pada Tabel 6 adanya penambahan jumlah daun seiring dengan bertambahnya umur tanaman. Walaupun secara statistik perlakuan pemberian air berdasarkan perbedaan metode pengukuran KAKL tidak berpengaruh nyata, namun dari hasil pengamatan, penyiraman berdasarkan KAKL yang diukur dengan metode Alhricks yang menghasilkan jumlah daun paling banyak.
Diameter Batang. Hasil sidik ragam menunjukkan pengaruh penyiraman berdasarkan KAKL yang diukur dengan metode berbeda tidak berpengaruh nyata terhadap diameter batang pada umur 2-10 MST pada tekstur liat. Meskipun demikian dapat dilihat pada Tabel 7 adanya peningkatan diameter batang tanaman seiring dengan bertambahnya umur tanaman. Penyiraman berdasarkan KAKL yang diukur dengan metode Pressure plate menghasilkan diameter batang yang paling besar.

Tabel 7. Pengaruh pemberian air berdasarkan KAKLyang diukur dengan metode berbeda terhadap pertumbuhan diameter batang (mm)

\begin{tabular}{|c|c|c|c|}
\hline \multirow{2}{*}{$\begin{array}{l}\text { Umur } \\
\text { Tanaman } \\
\text { (MST) }\end{array}$} & \multicolumn{3}{|c|}{ Metode Penetapan Kadar Air Kapasitas Lapang } \\
\hline & $\begin{array}{c}\text { Metode Alhricks (KAKL } \\
55.89 \%-\mathrm{B})\end{array}$ & $\begin{array}{l}\text { Metode Drainase Bebas } \\
\text { (KAKL 54.13\%-B) }\end{array}$ & $\begin{array}{l}\text { Metode Pressure Plate } \\
\text { (KAKL 76.53-B) }\end{array}$ \\
\hline 2 & $7.30 \mathrm{a}$ & $6.50 \mathrm{a}$ & $7.00 \mathrm{a}$ \\
\hline 3 & $9.27 \mathrm{a}$ & $9.17 \mathrm{a}$ & $10.20 \mathrm{a}$ \\
\hline 4 & $10.17 \mathrm{a}$ & $10.15 \mathrm{a}$ & $12.95 \mathrm{a}$ \\
\hline 5 & $10.43 \mathrm{a}$ & $10.37 \mathrm{a}$ & $13.48 \mathrm{a}$ \\
\hline 6 & $10.57 \mathrm{a}$ & $10.67 \mathrm{a}$ & $13.53 \mathrm{a}$ \\
\hline 7 & $10.30 \mathrm{a}$ & $10.43 \mathrm{a}$ & $13.58 \mathrm{a}$ \\
\hline 8 & $10.32 \mathrm{a}$ & $10.43 \mathrm{a}$ & $13.65 \mathrm{a}$ \\
\hline 9 & $10.28 \mathrm{a}$ & $10.43 \mathrm{a}$ & $13.65 \mathrm{a}$ \\
\hline 10 & $10.28 \mathrm{a}$ & $10.43 \mathrm{a}$ & $13.65 \mathrm{a}$ \\
\hline
\end{tabular}

Tabel 8. Pengaruh penyiraman berdasarkan KAKL yang diukur dengan metode berbeda terhadap perakaran

\begin{tabular}{lccc}
\hline Perlakuan & $\begin{array}{c}\text { Biomassa akar } \\
\text { basah (g) }\end{array}$ & $\begin{array}{c}\text { Biomassa akar } \\
\text { kering (g) }\end{array}$ & $\begin{array}{c}\text { Panjang akar } \\
(\mathrm{cm})\end{array}$ \\
\hline Metode Alhricks (KAKL 55.89\%-B) & $24.85 \mathrm{ab}$ & $12.01 \mathrm{a}$ & $28.20 \mathrm{ab}$ \\
Metode Drainase Bebas (KAKL 54.13\%-B) & $10.88 \mathrm{~b}$ & $3.98 \mathrm{a}$ & $23.67 \mathrm{~b}$ \\
Metode Pressure Plate (KAKL 76.53\%-B) & $50.42 \mathrm{a}$ & $20.47 \mathrm{a}$ & $40.83 \mathrm{a}$
\end{tabular}

Keterangan: Angka pada kolom yang sama yang diikuti oleh huruf yang sama menunjukkan tidak berbeda nyata berdasarkan uji Duncan pada taraf $5 \%$

Perakaran. Berdasarkan hasil sidik ragam, pengaruh penyiraman berdasarkan perbedaan metode pengukuran kadar air kapasitas lapang tidak berpengaruh nyata terhadap biomassa akar kering, namun berpengaruh terhadap biomassa akar basah serta panjang akar.

Pada Tabel 8 di atas menunjukkan bahwa bobot biomassa akar basah dan panjang akar tertinggi terdapat pada perlakuan tanaman dengan penyiraman yang didasarkan pada KAKL yang diukur dengan metode Pressure plate. Penambahan air yang semakin meningkat akan meningkatkan pertumbuhan tanaman.

Biomassa Tajuk. Berdasarkan hasil sidik ragam, pengaruh pemberian air berdasarkan perbedaan metode pengukuran kadar air kapasitas lapang berpengaruh nyata terhadap biomassa tajuk (basah maupun kering).

Tabel 9 menunjukkan bahwa biomassa tajuk (basah maupun kering) terbesar ditunjukkan oleh pemberian air berdasarkan KAKL yang diukur dengan metode Pressure plate yang merupakan kadar air yang paling tinggi. Pemberian air yang lebih banyak akan meningkatkan ketersediaan air di dalam tanah. Meningkatnya bobot basah maupun kering tajuk disebabkan karena meningkatnya kemampuan tanah dalam menyerap air dan sumber hara mineral di dalam tanah.
Tabel 9. Pengaruh pemberian air berdasarkan KAKL yang diukur dengan metode berbeda terhadap biomassa tajuk

\begin{tabular}{|c|c|c|}
\hline Perlakuan & $\begin{array}{l}\text { Biomassa } \\
\text { basah }(\mathrm{g})\end{array}$ & $\begin{array}{l}\text { Biomassa } \\
\text { kering }(g)\end{array}$ \\
\hline $\begin{array}{l}\text { Metode Alhricks (KAKL 55.89\%- } \\
\text { B) }\end{array}$ & $100.98 \mathrm{~b}$ & $24.41 \mathrm{~b}$ \\
\hline $\begin{array}{l}\text { Metode Drainase Bebas (KAKL } \\
54.13 \%-B \text { ) }\end{array}$ & $79.38 \mathrm{~b}$ & $17.61 \mathrm{~b}$ \\
\hline $\begin{array}{l}\text { Metode Pressure Plate (KAKL } \\
76.53 \%-\mathrm{B})\end{array}$ & $233.20 \mathrm{a}$ & $57.58 \mathrm{a}$ \\
\hline $\begin{array}{l}\text { Angka pada kolom ya } \\
\text { yang sama menunj } \\
\text { berdasarkan uji Duncan }\end{array}$ & $\begin{array}{l}\text { ma yang d } \\
\text { tidak } \\
\text { taraf } 5 \%\end{array}$ & $\begin{array}{l}\text { oleh huruf } \\
\text { eda nyata }\end{array}$ \\
\hline
\end{tabular}

\section{SIMPULAN}

Masing-masing perlakuan yaitu tekstur tanah, metode pengukuran KAKL, serta interaksi antara tekstur tanah dan metode pengukuran KAKL berpengaruh nyata terhadap nilai kadar air kapasitas lapang. Kadar air kapasitas lapang pada tekstur liat lebih besar daripada tekstur lempung liat berpasir dan lempung berpasir. Pengukuran dengan metode Pressure Plate menghasilkan nilai KAKL yang paling tinggi diantara metode lainnya. Pada penetapan kadar air kapasitas lapang dengan metode Alhricks, ketebalan pasir kuarsa yang paling baik adalah 6 $\mathrm{cm}$ dan tanah $3 \mathrm{~cm}$, karena data kadar air yang diperoleh 
lebih konsisten serta menghasilkan nilai $\mathrm{R}^{2}$ yang paling tinggi.

Pada perlakuan tekstur, terdapat perbedaan respon pertumbuhan yang nyata. Pada tanaman yang ditanam di media bertekstur liat dapat tumbuh hingga $10 \mathrm{MST}$ sedangkan pada media bertekstur lempung liat berpasir dan lempung berpasir mengalami kematian pada 2-3 MST. Pada tekstur liat perlakuan penyiraman yang didasarkan pada KAKL tidak berpengaruh nyata terhadap tinggi tanaman, jumlah daun, diameter batang, dan biomassa akar kering namun berpengaruh nyata terhadap biomassa akar basah, biomassa tajuk basah dan kering, serta panjang akar.

\section{UCAPAN TERIMA KASIH}

Penulis menyampaikan penghargaan dan terima kasih kepada para pegawai Laboratorium dan rumah kaca University Farm IPB, serta semua pihak yang telah banyak membantu selama penelitian berlangsung.

\section{DAFTAR PUSTAKA}

Baskoro, D.P.T. dan S.D. Tarigan. 2007. Karakteristik kelembaban tanah pada beberapa jenis tanah. $J$ Tanah Lingk., 9:77-81.

Hasugian, R.R. 1994. Pengaruh penambahan pasir dengan ketersediaan air maksimum pada tanah paleudult tipik parung dan pertumbuhan tanaman bunga matahari (Helianthus annuus L.) [Skripsi]. IPB. Bogor.

Jury, W.A., W.R. Gardener, and W.H. Gardener. 1991. Soil Physics 5ed. J Wiley. New York.

Kurnia, U., F. Agus, A. Adimiharja, dan A. Dariah. 2006. Sifat Fisik Tanah dan Metode Analisisnya. Balai Penelitian dan Pengembangan Pertanian Departemen Pertanian. Jakarta.

Lado, M., A. Paz, and M. Ben-Hur. 2004. Organic metter and agregrat size interaction. Soil Sci Soc Am J., 68:234-242.

Leiwakabessy, F.M., U.M. Wahjudin, dan Suwarno. 2003. Kesuburan Tanah. Jurusan Tanah, Fakultas Pertanian, Institut Pertanian Bogor. Bogor.

Rusdi, D. 2003. Karakterisasi sifat fisika tanah pada berbagai tekstur dan jenis tanah [Skripsi]. IPB. Bogor.

Sulaeman, D. 2011. Efek kompos limbah baglog jamur tiram putih terhadap sifat fisik tanah serta pertumbuhan bibit markisa kuning [Skripsi]. IPB. Bogor.

Supriyanto. 1996. Kajian pengukuran kapasitas lapang pada tanah-tanah tropika. Agr UMY., 4:13-16 